\title{
CLIMATIC INFERENCES FROM FORMER GLACIERS IN THE SOUTH-EAST GRAMPIAN HIGHLANDS, SCOTLAND
}

\author{
By J. B. Sissons and D. G. Sutherland \\ (Department of Geography, University of Edinburgh, Edinburgh EH I INR, Scotland)
} ABstract. Altitudes, lengths, areas, maximum thicknesses and volumes of 27 glaciers that built up in a
small area of the Scottish Highlands during the Loch Lomond (Younger Dryas) stadial are given. The
influence of direct radiation on the glaciers is calculated taking into account transmissivity of the atmosphere,
glacier aspect and surface gradient, and the albedos of ice and snow. Equilibrium firn lines for the glaciers
are determined. The computed regional firn line, incorporating the influence of direct radiation, had a
gradient of $14.5 \mathrm{~m} / \mathrm{km}$. Former precipitation values are based on an equation for average annual mass
balances of the glaciers during the stadial that incorporates glacier altitude, regional ablation gradient, direct
radiation, the influence of avalanching and blowing of snow, and final glacier volume. Average July and
January sea-level temperatures of $6^{\circ} \mathrm{C}$ and at least $-8^{\circ} \mathrm{C}$, respectively, are inferred. Snowfall was principally
associated with south-east winds and was similar in total to present day but rather differently distributed.
Cloud amounts, at least in summer, were greater than now. A more vigorous atmospheric circulation with
many depressions moving along more southerly tracks than now may have been related to the junction of
polar water and North Atlantic Drift water in the immediate vicinity of the British Isles.

RÉsumÉ. Implications climatiques de la dernière glaciation dans le sud-est des Grampian Highlands, Écosse. Les altitudes, les longueurs, les surfaces, les épaisseurs maximum et les volumes de 27 glaciers qui se sont installés dans un petit secteur des Highlands Ecossais durant le stade de Loch Lomond (Dryas récent) sont connus. On a calculé l'influence de la radiation directe sur les glaciers en prenant en compte la transmittivité de l'atmosphère, le relief́ du glacier, la pente de sa surface, les albedos de la glace et de la neige. On a déterminé les lignes de névés des glaciers. La ligne de névé régionale, compte tenu de l'influence du rayonnement direct, avait un gradient de $14,5 \mathrm{~m} / \mathrm{km}$. On a proposé les valeurs pour les précipitations à cette époque à partir d'une équation donnant les bilans annuels des glaciers durant le stade selon l'altitude du glacier, le gradient régional d'ablation, la radiation directe, l'influence des avalanches et du vent sur l'accumulation de la neige, et le volume final du glacier. On en déduit des températures moyennes au niveau de la mer en juillet et janvier de, respectivement, $6^{\circ} \mathrm{C}$ et au moins $-8^{\circ} \mathrm{C}$. Les chutes de neige étaient surtout associées avec les vents du Sud-Est et étaient au total, semblables à celles de la période actuelle, mais distribuées de manière assez différente. La nébulosité était, au moins en été, plus grande que maintenant. Une circulation atmosphérique plus active avec de nombreuses dépressions suivant des itinéraires plus méridionaux que de nos jours peut être expliquée par le contact, dans le voisinage immédiat des Îles Britanniques, des eaux polaires et des eaux du Courant Nord Atlantique.

Zusammenfassung. Klimatische Schlüsse aus früheren Gletschern im südöstlichen Grampian Highlands, Schottland. Von 27 Gletschern, die sich in einem kleinen Bereich des Schottischen Hochlandes während des Loch Lomond- (Jüngeren Dryas-) Stadiums gebildet hatten, werden die Höhen, Längen, Flächen, maximalen Dicken und Volumina mitgeteilt. Der Einfluss der direkten Strahlung auf die Gletscher wurde unter Berücksichtigung der Durchlässigkeit der Atmosphäre, der Exposition und Oberflächenneigung der Gletscher sowie der Albedo von Eis und Schnee berechnet. Die Gleichgewichtslinien der Gletscher wurden bestimmt. Die berechnete regionale Firnlinie hatte unter Einschluss des direkten Strahlungseinflusses einen Gradienten von $14,5 \mathrm{~m} / \mathrm{km}$. Für den damaligen Niederschlag werden Werte vorgeschlagen, die auf einer Gleichung für den mittleren jährlichen Massenhaushalt der Gletscher während des Stadials mit den Parametern Gletscherhöhe, regionaler Ablationsgradient, direkte Strahlung, Einfluss von Lawinen und Schneedrift und Gletschervolumen beruhen. Für Juli und Januar werden Temperaturen von $+6^{\circ} \mathrm{C}$ bzw. mindestens $-8^{\circ} \mathrm{C}$ angenommen. Der Schneefall war meist mit Süd-Ost-Winden verbunden und entsprach in seiner Gesamtmenge den heutigen Verhältnissen, jedoch bei sehr verschiedener Verteilung. Die Bewölkung war stärker als høute, zumindest im Sommer. Eine kräftigere atmosphärische Zirkulation mit vielen Depressionen, deren Bahnen weiter südlich verliefen als heute, könnte in Zusammenhang mit der Vermischung polaren Wassers und Drift-Wassers aus dem Nord-Atlantik in unmittelbarer Nachbarschaft der Britischen Inseln gestanden haben.

\section{INTRODUCTION}

This paper seeks to demonstrate that much may be inferred about past climates from former glaciers if a glaciological treatment is adopted. It uses 27 former glaciers in the south-east Grampians to illustrate this.

Following the decay of the last ice sheet, glaciers built up anew at hundreds of locations in the Scottish Highlands and islands, the Southern Uplands of Scotland, the English Lake District, Snowdonia, etc. This Loch Lomond re-advance (= Younger Dryas) normally left 


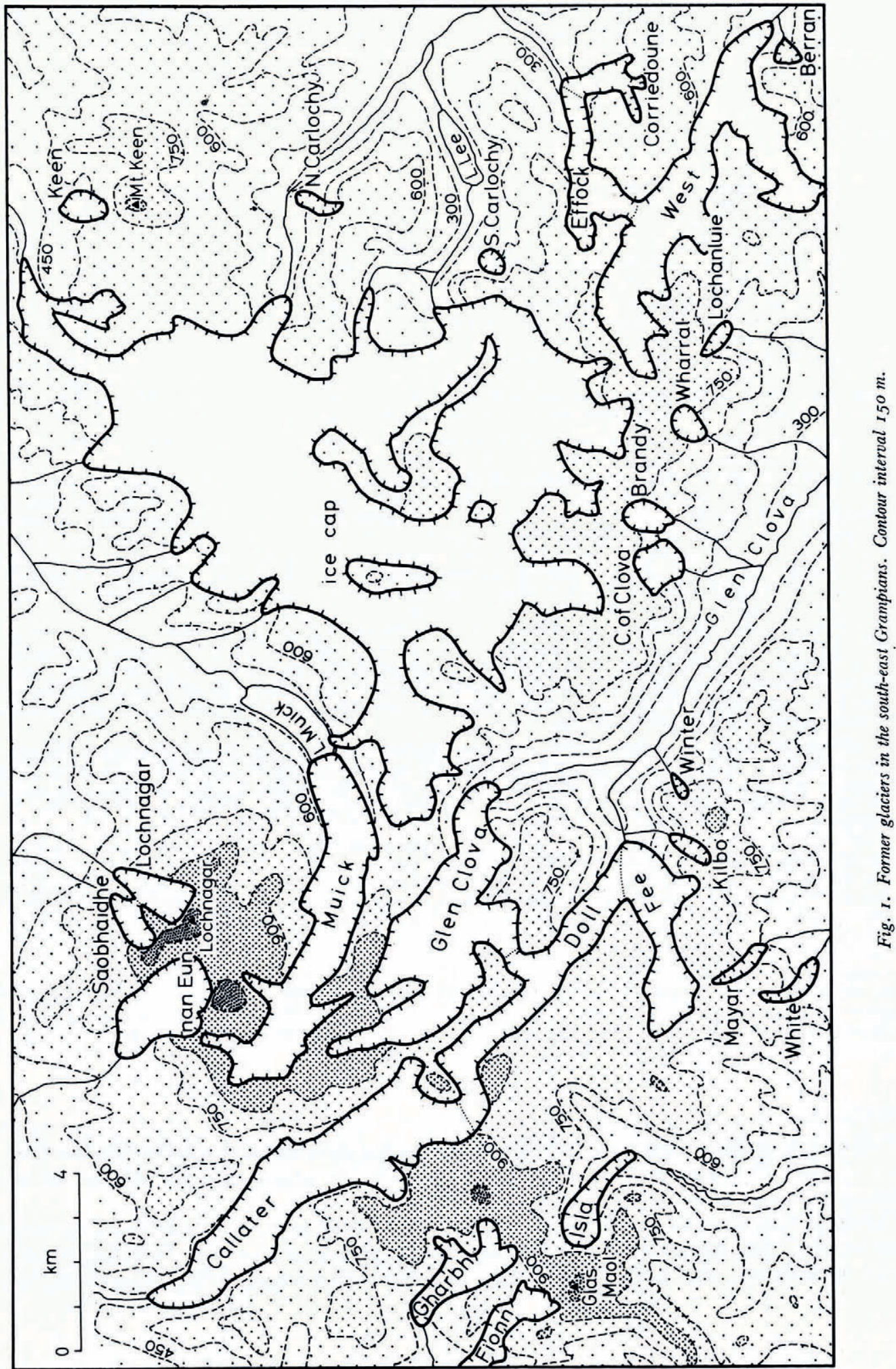


abundant geomorphic evidence that permits detailed reconstruction of the former glaciers. These glaciers have been utilized to a significant degree only by Manley (1959) in an ingenious discussion of the late-glacial climate of the Lake District. The present contribution uses some of Manley's lines of reasoning but adopts a more quantitative and detailed approach.

Since analogies with modern glaciers are necessary to permit inferences from former glaciers, Norwegian data, particularly from Jotunheimen, are used. This area differs only a few degrees in latitude from the south-east Grampians, has rather similar relief (although actual altitudes are much higher) and contains glaciers of similar dimensions to those that existed in the south-east Grampians, while data relating to glacier mass balances are available.

\section{Relief AND LOcATION}

The area is located just within the Scottish Highlands, its south-eastern corner being only $8 \mathrm{~km}$ from the Highland Boundary Fault, in the vicinity of which the ground rises rapidly from the lowland of Strathmore. Most of the higher ground is an undulating plateau at $600-950 \mathrm{~m}$. The latter altitude is exceeded only in the north-west, where Glas Maol rises to $\mathrm{I} 067 \mathrm{~m}$ and Lochnagar attains I $154 \mathrm{~m}$ (Fig. I). The plateau is cut into by glacial troughs which, while locally impressive, are of modest dimensions by Alpine standards. Among the corries in the area are a group facing northward on Lochnagar and a group facing almost due south by Glen Clova.

\section{Geomor Phic EVIDENCE}

The geomorphic evidence for the former glaciers (excepting three) has been given elsewhere (Sissons, 1972; Sissons and Grant, 1972) and will therefore be mentioned briefly here. The termini of 16 of the former glaciers are recorded by terminal moraines and those of two others by an abrupt limit to large ice-transported boulders. The termini of almost all the remaining glaciers are marked by the down-valley limit of fresh hummocky moraines and are also often associated with outwash terraces. The lateral extent of most of the very small glaciers is defined by lateral moraines and boulder limits that continue the terminal moraines to the steep slopes beneath which the glaciers accumulated. Hummocky moraines on valley slopes and on the plateau give minimal altitudes for the lateral margins of many of the larger glaciers, while lateral moraines intermittently define the former margins of some of these glaciers. In the north-west, and on Mount Keen in the north-east (Fig. I), numerous massive solifluction lobes composed of granite boulders occur; where end (including lateral) moraines are present, these lobes are not found within them and hence can be used to define the maximum possible extent of the former glaciers. Such evidence, along with the snowaccumulation areas usually being obvious, enables the former extent of the glaciers to be plotted with considerable confidence.

On the other hand, while geomorphic evidence enables the limits of most of the outlet glaciers of the plateau ice cap to be inferred, the limit elsewhere is tentative and based on indirect evidence. For this reason, calculations were made both including and excluding the ice cap. It was found, however, that omission of the ice cap had no significant effect on regional patterns and hence it is included in the results given below. This suggests that the reconstruction of the ice cap is not seriously in error.

Glacier surfaces were contoured on the $\mathrm{I}: 25$ ooo scale using a $50 \mathrm{~m}$ interval, account being taken of terminal convexity, form of the bounding slopes, bed gradient, and localities of convergent and divergent flow. Various dimensions of the former glaciers when at their greatest extent are given in Table I. Areas were measured by superimposing on the map a grid of squares with side equivalent to $100 \mathrm{~m}$. Glacier thickness and volume were determined from a rectangular grid of points ( $100 \mathrm{~m}$ or less depending on glacier size), estimates of drift thickness being made where necessary. 


\begin{tabular}{|c|c|c|c|c|c|c|}
\hline Glacier & $\begin{array}{c}\text { Altitude } \\
\text { range } \\
\mathrm{m}\end{array}$ & $\begin{array}{l}\text { Area } \\
\mathrm{km}^{2}\end{array}$ & $\begin{array}{c}\text { Maximum } \\
\text { thickness } \\
\mathrm{m}\end{array}$ & $\begin{array}{c}\text { Volume } \\
\mathrm{km}^{3}\end{array}$ & $\begin{array}{c}\text { Length } \\
\mathrm{km}\end{array}$ & $\begin{array}{c}\text { Equilibrium } \\
\text { firn line } \\
\mathrm{m}\end{array}$ \\
\hline Lochnagar & $690-970$ & I. 31 & 140 & 0.074 & I. 8 & 860 \\
\hline Saobhaidhe & $710-1030$ & 0.72 & 55 & 0.016 & I. 4 & $85^{\circ}$ \\
\hline nan Eun & $660-1020$ & $3 \cdot 18$ & 100 & o. 145 & 2.8 & 884 \\
\hline Gharbh & $570-930$ & 2.1 6 & 105 & 0.090 & 3.0 & 769 \\
\hline Fionn & $530-930$ & 1. 66 & 85 & 0.057 & 2.9 & 762 \\
\hline Isla & $460-840$ & 1.27 & 85 & $0.04^{2}$ & 2.5 & 64 I \\
\hline Callater & $44^{\circ}-9^{20}$ & 10.90 & 235 & 1.030 & 8.5 & 718 \\
\hline Muick & $400-1000$ & 9.07 & 215 & 0.804 & 8.2 & 761 \\
\hline Glen Clova & $280-970$ & $9 \cdot 5^{1}$ & $24^{\circ}$ & $0.59^{\circ}$ & 8.0 & 732 \\
\hline Doll & $320-920$ & $5 \cdot 19$ & 170 & 0.279 & $7 \cdot 5$ & 737 \\
\hline Fee & $320-870$ & 4.05 & 160 & 0.205 & $4 \cdot 5$ & 681 \\
\hline Mayar & $570-800$ & $0.4^{1}$ & 75 & 0.011 & 1.5 & 695 \\
\hline White & $500-75^{\circ}$ & 0.49 & 70 & 0.014 & 1. 6 & 640 \\
\hline Kilbo & $55^{0}-810$ & 0.39 & 70 & 0.014 & I. I & 688 \\
\hline Winter & $460-700$ & 0.12 & 40 & 0.002 & 0.6 & $59^{8}$ \\
\hline Corrie of Clova & $520-750$ & $0.9^{8}$ & I5o & 0.066 & I. I & 660 \\
\hline Brandy & $600-760$ & 0.65 & 90 & 0.029 & I. 2 & 690 \\
\hline Wharral & $620-760$ & 0.50 & 80 & 0.021 & 0.9 & 690 \\
\hline Lochanluie & $5 \mathrm{IO}-780$ & 0.30 & 80 & 0.008 & 1.0 & 664 \\
\hline Keen & $480-760$ & 0.59 & 95 & 0.024 & I. 1 & 623 \\
\hline North Carlochy & $3^{10-} 580$ & 0.32 & 100 & 0.013 & 1.2 & 459 \\
\hline Ice cap & $390-820$ & 66.18 & 150 & 2.927 & - & 690 \\
\hline West & $330-840$ & 10.83 & 140 & 0.430 & 9.0 & 643 \\
\hline Effock & $290-700$ & 2.42 & Iio & 0.080 & 3.8 & 574 \\
\hline South Carlochy & $400-570$ & 0.25 & 100 & 0.012 & 0.6 & 497 \\
\hline Corriedoune & $290-640$ & I.04 & 120 & 0.047 & 2.3 & $5^{12}$ \\
\hline Berran & $400-5^{60}$ & 0.25 & $4^{\circ}$ & 0.005 & 0.6 & 493 \\
\hline
\end{tabular}

\section{INSOLATION FAGTOR}

In seeking to explain the distribution and altitude of the glaciers, four factors for which quantitative data (of varying degrees of accuracy) could be obtained were considered. These are direct solar radiation, shadow, and avalanching and blowing of snow.

The influence of direct radiation was calculated for lat. $57^{\circ} \mathrm{N}$. for five times of day (o8.oo, I $0.00, \mathrm{I} 2.00, \mathrm{I} 4.00$ and $\mathrm{I} 6.00 \mathrm{~h}$ ) on each of $\mathrm{I}_{5} \mathrm{~d}$ at $10 \mathrm{~d}$ intervals from 5 May to 22 September (covering the probable ablation season by analogy with Jotunheimen), taking into account the transmissivity of the atmosphere (taken as 0.7 ), the aspect and gradient of the glacier surfaces and the albedos of ice and snow. Since the albedos of ice and snow vary considerably, typical average values were used: $30 \%$ for ice and $60 \%$ for snow for surfaces perpendicular to the sun's rays. Curves relating the angle of incidence of the sun's rays to the albedos of dry sand, wet sand and a water surface in movement have been given by Geiger (1971, p. I7). Since these curves are all of the same form, similar curves were drawn for ice and snow surfaces, and the values derived from these were used in calculations.

Two sets of values were obtained: one for ice and one for snow surfaces. Since the transient snow line gradually retreats up a glacier surface during the ablation season, the line dividing the snow-covered area from the area in which ice is exposed may be approximated as the line whose altitude is midway between the lowest point on the glacier and the altitude of the firn line at the end of the ablation season (in this case the equilibrium firn line (p. 330)). This line was drawn on the glacier maps and the appropriate values of insolation were then determined for a rectangular grid of points, point spacing varying from 200 to $50 \mathrm{~m}$ depending on glacier size. This procedure was greatly speeded up by constructing circular graphs on transparent overlays from which values could be read directly from the spacing of the glacier contours. The values obtained for all the sample points on a glacier were summed and averaged, thus giving for each glacier a single value, which is referred to as its insolation factor. 
The insolation factor cannot be used to give absolute values of direct radiation absorbed by the glaciers since the former cloud cover is not known. However, it does give a measure of the relative importance of direct insolation on different glaciers. The value for a horizontal glacier is $c$. 12.7. The lowest value obtained is 8.8 for north-facing Keen glacier, while the highest values (14.5-15.8) are for the south-facing glaciers by Glen Clova.

\section{Effect of Shadow}

The effect on radiation received by glaciers of shading by higher ground has been calculated by various workers (e.g. Ferguson and others, 197 I; Goodison, 1972). The effect of shadow on direct radiation was considered as a possible factor affecting glacier distribution. However, it was found to be insignificant. One reason is the rather limited relief amplitude of the area. More important is that the glaciers generally sloped away from the rock walls that were the main cause of shadow. This is especially true of the smallest glaciers where shading would have been proportionately most significant. Consequently, for the relatively low sun angles when shading could have become important, almost all the direct radiation would have been reflected even if rock walls had not provided shadow. This is particularly so because the higher parts of the glaciers, which were most shaded by high ground, would normally have been permanently covered by snow with its high albedo. The effect of shadow was therefore ignored.

\section{Avalanching AND Blowing of SNOw}

Fraser (1966, p. 99) stated: "Avalanches can occur on slopes down to $22^{\circ}$ and in special circumstances on slopes of even less gradient". Hence slopes over $20^{\circ}$ (as determined from the $1: 25$ ooo map) that led directly down to the former glaciers above the equilibrium firn

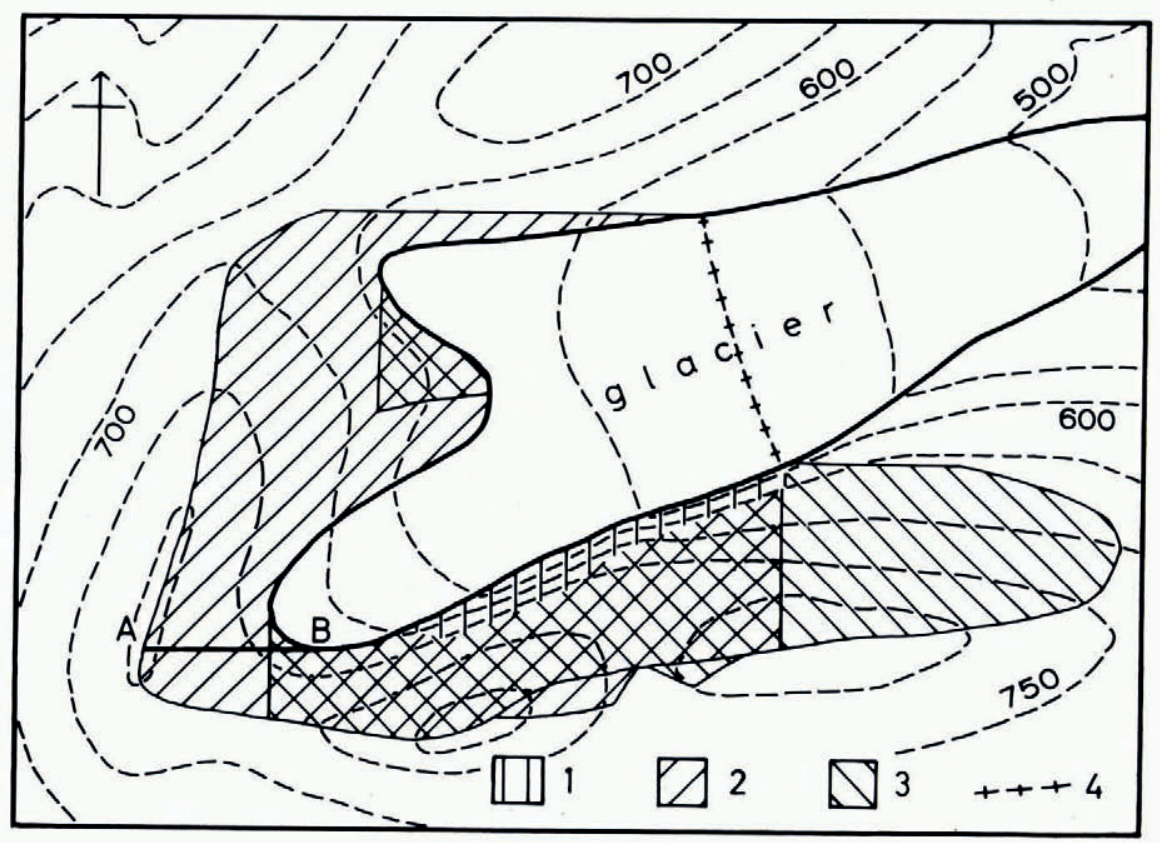

Fïg. 2. Delimitation of areas from which snow may have avalanched and been blown on to glaciers: 1. Potential avalanching area; 2. Area of potential snow-blowing in south-west quadrant ; 3. Area of potential snow-blowing in south-east quadrant; 4. Equilibrium firn line. 
line (see below) were measured. Almost all these slopes considerably exceed $20^{\circ}$. The area from which snow could have been blown on to a glacier was drawn to include all points that could be connected to the glacier surface above the equilibrium firn line by a straight line with a continuous downhill slope along the ground surface. The outer limit of the potential snow-blowing area for a glacier thus corresponds roughly with the drainage divide surrounding its accumulation area (Fig. 2). It is recognized that snow often blows uphill; if the downhill constraint is not adopted, however, it becomes necessary to adopt an arbitrary limiting gradient for the uphill transfer of snow. Furthermore, since the former glaciers were often situated close together, this would result in extensive areas being assigned to more than one glacier. Since the frequency of winds from different directions was considered likely to have been important in the blowing of snow, the four quadrants (south to west, etc.) were measured separately.

Examination of the data showed marked differences between some glaciers. Despite its large area, the plateau ice cap lacked any potential avalanching areas above its equilibrium line. The same is true of adjacent West and Effock glaciers nourished in rather shallow plateau valleys. Expectably, potential avalanching areas for small corrie glaciers were normally large relative to glacier area. The ice cap had by far the largest potential snow-blowing area $\left(17 \mathrm{~km}^{2}\right)$, much of this being gently sloping ground on its southern side. The most notable among other relationships is that the exceptionally low altitude of North Carlochy glacier appears to be mainly a consequence of the large plateau surface to the south from which snow could have been blown on to the glacier.

\section{EQUILIBRIUM FIRN LINES}

Since the former glaciers being considered were at their greatest extent, they can be regarded as having been in equilibrium, on average, over a number of years. The firn line at the end of the ablation season would be the equilibrium firn line, total accumulation above it being equal to total ablation below it. Therefore, if accumulation and ablation were each linearly related to altitude over the whole altitudinal range of the glacier, the equilibrium firn line on a glacier can be calculated from

$$
f=\frac{\sum_{i=0}^{n} A_{i} h_{i}}{\sum_{i=0}^{n} A_{i}}
$$

where $f$ is the altitude of the firn line $(\mathrm{m}), A_{i}$ is the glacier surface area within contour interval $i$ $\left(\mathrm{km}^{2}\right), h_{i}$ is the altitude of the mid point of contour interval $i$, and $n+\mathrm{I}$ is the number of contour intervals (Sissons, 1974[a]).

The linear generalization of accumulation and ablation gradients has been made in some studies of modern glaciers (e.g. Schytt, 1967; Chorlton and Lister, 1971). To test the effect of non-linear gradients, calculations were made with hypothetical values. It was found that, unless improbable values are introduced, the change in firn-line altitude is small; the dominant control is the areal distribution of the glacier surface with altitude.

\section{Regional FIRN LINE}

The equilibrium firn lines show a clear tendency to rise from south-east to north-west but there are local variations (Fig. 3). It was anticipated that the latter might be related particularly to the insolation factor and perhaps also to the areas of potential avalanching and snow-blowing. Initial calculations showed, however, that the last two have no significant effect on the regional firn line. 


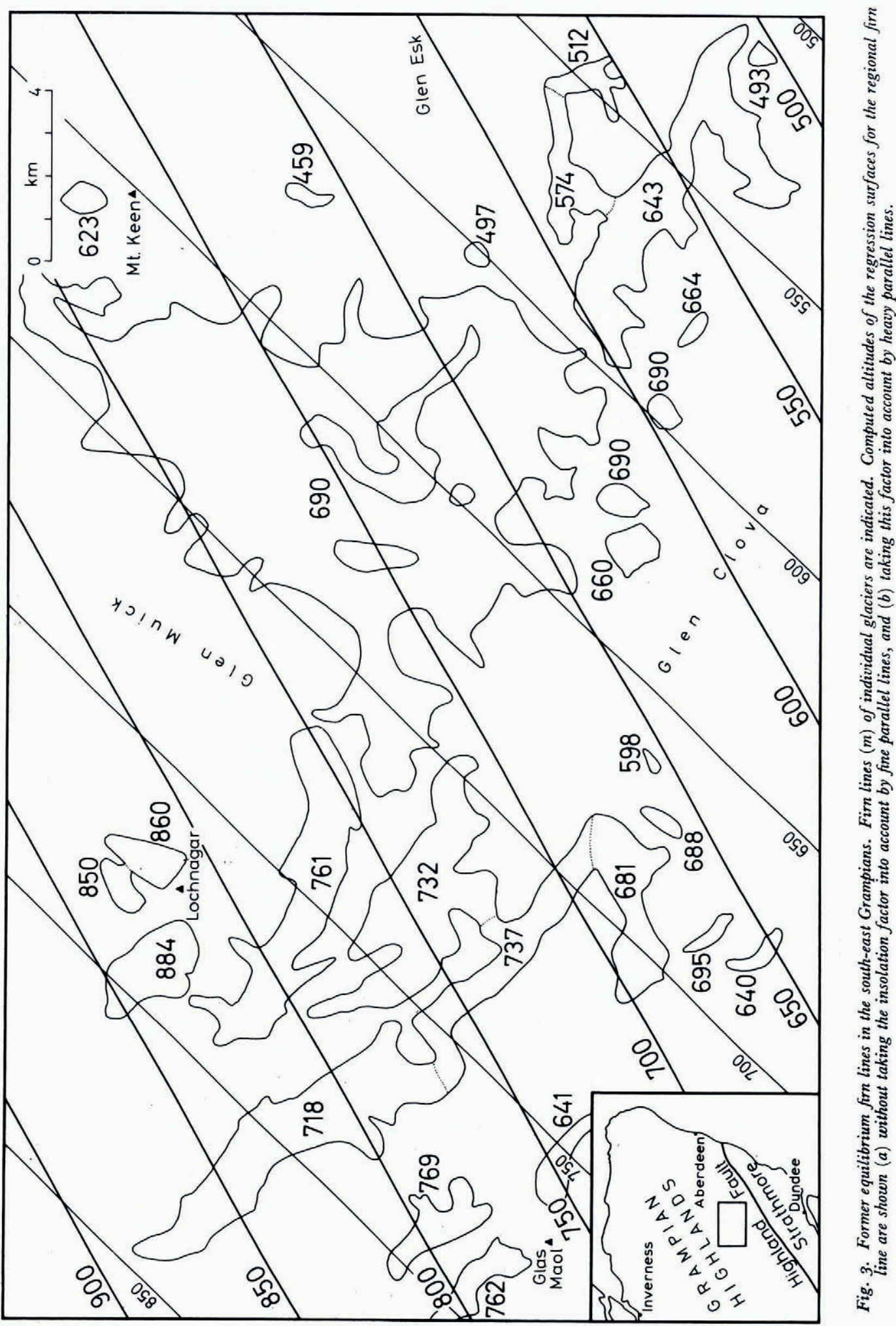


To examine the statistical association between the equilibrium firn-line altitudes, the National Grid coordinates of the glaciers (taken as the mid point of the firn line, except for the ice cap where its approximate centre point was used), and the insolation factor, a multiple stepwise regression approach was adopted using the standard package program BMDo2 $\mathrm{R}$ (Dixon, I973). For this purpose, the distribution of firn-line altitudes should be normal or close to normal, a requirement that is fulfilled. A further requirement is that the data should not be clustered. This was tested using Clarke and Evans's (1954) nearest-neighbour statistic, where a value of 0.0 represents "complete" clustering, I.o a random distribution, and 2. I 6 a hexagonal distribution. The value of $\mathrm{I}: \mathrm{I} 3$ that was obtained is close to random. The values for the insolation factor were expressed as differences, in the proportion of solar radiation that would have been received by each glacier, from that which would have been received by a hypothetical horizontal glacier.

The altitude of the regional firn line $(F)$ is most closely dependent on the grid eastings $(E)$ (correlation coefficient, $r=-0.7 \mathrm{I}$ ). This is followed by a weaker relationship with the northings $(N)(r=0.44)$ which, together with the eastings, define a surface that represents the general trend across the area of the firn-line altitude (Fig. 3):

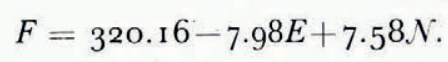

This surface, which has a degree of statistical explanation of $61 \%(r=0.78)$, has a maximum gradient of $11.0 \mathrm{~m} / \mathrm{km}$, the direction of the isolines being N. $42^{\circ} 4 \mathrm{o}^{\prime} \mathrm{E}$. (in terms of the National Grid).

The incorporation of the insolation factor $(I)$ in the regression equation increases the level of explanation to $72 \%(r=0.85)$. This final regression equation is

$$
F=-74.13-7.34 E+12.49 \mathcal{N}+22.35 I \text {. }
$$

A quantity $Z$ can be defined as $(F-22.35 I)$ and the distribution of $Z$ across the area is represented by the equation

$$
z=-74.13-7 \cdot 34 E+12.49 \mathcal{N}
$$

This surface (Fig. 3) has a maximum gradient of $14.5 \mathrm{~m} / \mathrm{km}$ and the direction of the isolines is N. $59^{\circ} 30^{\prime} \mathrm{E}$.

The quantity $Z$ is the altitude that the firn line would assume if insolation were distributed evenly across the glaciers. In other words, each unit of deviation of the insolation values from that of a horizontal glacier is equal to $22.35 \mathrm{~m}$ of change of altitude in the firn line associated with that deviation.

A striking feature of the isolines for the regional firn-line surface incorporating the insolation factor is that they are almost exactly parallel with the Highland edge. The Highland Boundary Fault, which may be taken as an objective representation of the Highland edge, trends N. $57^{\circ} \mathrm{E}$. The only major factor that could account for this relationship and for the steep gradient of the regional firn line is that snowfall at a given altitude decreased, on average, with increasing distance into the Highlands. Such a distribution could only occur if snowfall was dominantly associated with winds from a southerly or south-easterly direction.

Heavy precipitation at present is rarely associated with the prevailing westerly winds. Hay (1949), in a study of rainfall distribution in eastern Scotland based on the records for Aberdeen found that, of 38 heavy falls of rain (defined as $25 \mathrm{~mm}$ or more in $24 \mathrm{~h}$ ) in the period 1926-35, 35 were associated with depressions whose centres passed to the south of Aberdeen. He wrote (Hay, I949, p. I I) : “. . it appears that the majority of heavy or moderate falls of rain at Aberdeen are associated with the movement of a warm occlusion in a direction between east-north-east and north over the British Isles. In many of the situations where the heaviest falls occur, the isobars in the cold air preceding the front run nearly parallel to it, giving a gradient for strong south-east winds". Along the south-east-facing slope of the Highland edge, where the ground rises $500 \mathrm{~m}$ or more in a few kilometres, such effects will be 
magnified with very heavy precipitation related to orographic uplift. Hay's evidence, applied to past conditions, thus provides the simplest and hence most probable explanation of the former regional firn-line gradient.

Certain factors would have tended to diminish precipitation during the stadial in comparison with present precipitation. Particularly important is the moisture content of saturated air which, with the temperatures that are likely to have prevailed to permit glaciers to form at all, would have been of the order of $40 \%$ below present average values. Furthermore, if, as seems likely, the northern North Sea was partly or wholly frozen over in winter (the bed of the southern part being land owing to low world sea-level), precipitation derived from this source, particularly the winter snow showers frequently associated with easterly air streams, would have been reduced or eliminated. Another point is that, as the stadial progressed and the mass of glacier ice that ultimately covered a large area of the western Highlands developed, precipitation from westerly air streams is likely to have been diminished in the south-east Grampians. Taking these factors into consideration, it appears unrealistic to expect precipitation in the south-east Grampians to have been much greater during the stadial than at present and the possibility clearly exists that it was far less.

On the I : 625 ooo Ordnance Survey rainfall map the 60 in ( $1524 \mathrm{~mm}$ ) isohyet is usually located at round $750 \mathrm{~m}$ and the 70 in $(1778 \mathrm{~mm}$ ) isohyet is not marked in any part of the area, suggesting that, in general, the higher ground currently receives between I 525 and I $780 \mathrm{~mm}$ precipitation. However, according to British rainfall, there are no rainfall stations on ground above $500 \mathrm{~m}$ within or near the south-east Grampians. On the other hand, the I : 625000 map as a whole is based on detailed analyses of rainfall data which, coupled with the experience of the compilers, make it "possible to deduce the general distribution of average rainfall in ... mountainous areas which are relatively poorly provided with data" (Bleasdale and Rowsel, r 967 , p. 6). This task is facilitated in the south-east Grampians by low precipitation gradients (i.e. rates of increase of precipitation with altitude).

\section{The Balance EQUATion}

In order to obtain a clearer picture of the distribution of precipitation and, if possible, of approximate absolute values of precipitation, an equation was developed from which the average snowfall on each glacier during its period of growth might be calculated. Although an infinite number of possible answers must exist for any one glacier considered in isolation, the former presence of 27 glaciers in a rather small area allows meaningful comparisons to be made between the snowfall determined for adjacent glaciers that enable many results to be dismissed as improbable. Evidence from modern Norwegian glaciers imposes further considerable constraints on the calculations.

Accumulation on a glacier may be regarded as consisting mainly of snow that falls, avalanches, and is blown on to it. Accumulation per unit area can therefore be expressed as

$$
\frac{S\left(A_{\mathrm{g}}+w A_{\mathrm{a}}+x A_{\mathrm{b}}\right)}{A_{\mathrm{g}}}
$$

where $S$ is snowfall, $A_{\mathrm{g}}$ is glacier area $\left(\mathrm{km}^{2}\right), A_{\mathrm{a}}$ is the area from which snow is liable to avalanche on to the glacier, $A_{\mathrm{b}}$ is the area from which snow blows on to the glacier, and $w$ and $x$ are constants. Since snowfall during the build-up of the glaciers is being calculated and since they grew from zero area to the limits shown in Figure $\mathrm{I}$, the average area of each glacier $\left(A_{\mathrm{g}}\right)$ during this period was approximated as the upper half of its final area as delimited by the mid-altitude line of the latter. (No attempt was made to re-draw the glaciers as they might have appeared at this time.) On some glaciers this mid-altitude line is almost exactly the same as the calculated equilibrium firn line discussed above; hence on these glaciers the values of $A_{\mathrm{a}}$ and $A_{\mathrm{b}}$ measured for the equilibrium glaciers were used. For the remaining glaciers these 
areas were re-measured on the I : 25 ooo map. The area from which snow was blown on to each glacier was taken to be the sum of the south-east and south-west quadrants for two reasons. First, it has been inferred above that precipitation was dominantly associated with south-east winds. Secondly, the prevailing wind appears to have been from between south and west, as indicated by the marked eastward rise of the former regional firn line in the western and northern Highlands of Scotland and by the former existence in these areas of glaciers at relatively low altitudes where blowing of snow from plateaux located to the southwest would have been favoured.

While numerous factors influence ablation (e.g. Paterson, r969), they may be simplified to two for present purposes, namely altitude and direct solar radiation. The former can be expressed as a linear ablation gradient. Since this gradient is applied to all the glaciers, it may be referred to as a regional ablation gradient. In order to apply such a gradient, it is necessary to include an absolute value of ablation at some altitude. This is most simply achieved by introducing an altitude of zero ablation.

The influence of direct solar radiation is represented by the insolation factor, which may be expressed in terms of the regional ablation gradient. As shown on p. 332, each unit of the insolation factor is equivalent to $22.35 \mathrm{~m}$ of altitude. This factor relates to the greatest extent of the glaciers; since only "half glaciers", which would normally have steeper gradients, are being considered here, $22.35 \mathrm{~m}$ was generalized as $25 \mathrm{~m}$. For example, since the insolation factor for a horizontal glacier is $c$. 1 2.7, an insolation factor of 14.7 can be regarded as equivalent to a depression of the firn line by $50 \mathrm{~m}$. With a regional ablation gradient of $300 \mathrm{~mm} /$ $100 \mathrm{~m}$ this would therefore be equivalent to increasing ablation by $150 \mathrm{~mm}$. Thus ablation ( $\mathrm{mm} /$ year) can be expressed as

$$
\frac{y I}{4}+\frac{y}{100}(z-\bar{H})
$$

where $I$ is the difference of the insolation factor from 12.7 (values below 12.7 being negative), $\bar{H}$ is the mean altitude $(\mathrm{m})$ of the highest and lowest points on the half glacier, $y$ is the regional ablation gradient $(\mathrm{mm} / \mathrm{r} 00 \mathrm{~m})$, and $z$ is the altitude of zero ablation.

Since the average mass balance during the period of glacier build-up is being considered, the volume of each glacier when at its greatest extent must be taken into account. Using $75^{\circ}$ years as the period of glacier growth (p. 339), the average increase in thickness per year of a half glacier, expressed in $\mathrm{mm}$ water equivalent, is

$$
\frac{0.9 \mathrm{~V} \times 10^{6}}{75^{0} A_{\mathrm{g}}}
$$

where $V$ is glacier volume $\left(\mathrm{km}^{3}\right)$ at the maximum and the density of glacier ice is taken as $0.9 \mathrm{Mg} / \mathrm{m}^{3}$.

The average annual mass balance for each glacier may therefore be represented by

$$
\frac{S\left(A_{\mathrm{g}}+w A_{\mathrm{a}}+x A_{\mathrm{b}}\right)}{A_{\mathrm{g}}}=\frac{y I}{4}+\frac{y}{\mathrm{I} 0 \mathrm{O}}(z-\bar{H})+\frac{9 V \times \mathrm{IO}^{4}}{75^{A}} .
$$

Given values for $w, x, y$ and $z$, average annual snowfall ( $\mathrm{mm}$ water equivalent) can then be calculated.

\section{Evaluation of THE constants in THE Balance EQUATION}

This equation was initially applied to the three former corrie glaciers on Lochnagar (nan Eun, Saobhaidhe and Lochnagar) at high altitudes in the north-west and to the two glaciers at low altitudes in the south-east (Corriedoune and Berran). To reduce the influence of local anomalies, the altitudes of these glaciers were compared in terms of the regression surface for the equilibrium firn line incorporating the insolation factor. For this surface the mean computed firn-line altitude for the three Lochnagar corrie glaciers is $825 \mathrm{~m}$ and for the two 
glaciers in the south-east $530 \mathrm{~m}$, equivalent to a temperature difference of $1.8 \mathrm{deg}$ assuming a temperature decrease of $0.6 \mathrm{deg} / \mathrm{r} 00 \mathrm{~m}$.

O. Liestøl (personal communication) has produced a graph based on certain Norwegian glaciers (Gråsubreen, Hellstugubreen, Storbreen, Hardangerjøkulen, Nigardsbreen and Alfotbreen) that relates accumulation and summer temperature (May-September average) at the equilibrium line. This graph shows that accumulation and summer temperatures are low in north-eastern Jotunheimen, successively larger accumulation at the equilibrium line on glaciers situated farther west being counterbalanced by the effect of rising temperature, the equilibrium line declining markedly in altitude westward (Liestøl, r 967).

Applied to the south-east Grampians, this graph enables possible values of snowfall at the Lochnagar corries to be compared with possible values in the extreme south-east, as set out in Table II.

TABle II. Comparison of POSSIBLe temperatures AND CORRESPONDING SNOWFall at LOCHNAGAR CORRIES AND AT BERRAN AND CORRIEDOUNE GLACIERS

$\begin{array}{cc}\begin{array}{c}\text { Summer temperature at two } \\ \text { glaciers in south-east }\end{array} & \begin{array}{c}\text { Corresponding } \\ \text { snowfall } \\ \text { mm w.e. }\end{array} \\ { }^{\circ} \text { C } & \text { I } 200 \\ \text { I } & \text { I } 595 \\ 2 & 2240 \\ 3 & 3380 \\ 4 & \end{array}$

$\begin{array}{cc}\begin{array}{c}\text { Summer temperature at } \\ \text { three Lochnagar corries }\end{array} & \begin{array}{c}\text { Corresponding } \\ \text { snowfall } \\ \text { mm w.e. }\end{array} \\ { }^{\circ} \mathrm{C} & 825 \\ -0.8 & 995 \\ 0.2 & 1260 \\ 1.2 & 1700 \\ 2.2 & \end{array}$

Snowfall was calculated from the balance equation for each of the five glaciers, using a wide range of values for $w, x$ and $y$, such that the mean snowfall for the two glaciers in the south-east was related to the mean snowfall for the three Lochnagar corrie glaciers by a temperature difference of $1.8 \mathrm{deg}$ on Liestøl's graph. Since in each set of calculations the values of $w, x$ and $y$ were fixed, this relationship was achieved by deriving the appropriate value for the altitude of zero ablation (approximated to the nearest $5 \mathrm{~m}$ ). Values of $w$ used in the

TABle III. Comparison of possible snowfall at three Lochnagar corries WITH POSSIBLE SNOWFALl ON BERRAN AND CORRIEDOUNE GLACIERS

\begin{tabular}{|c|c|c|c|c|c|}
\hline $\begin{array}{l}w \\
\%\end{array}$ & $\begin{array}{c}x \\
\%\end{array}$ & $\begin{array}{c}\text { Ablation } \\
\text { gradient } \\
\mathrm{mm} / \mathrm{I} 00 \mathrm{~m}\end{array}$ & $\begin{array}{c}\text { Altitude of } \\
\text { zero ablation } \\
\mathrm{m}\end{array}$ & $\begin{array}{c}\text { Average snowfall, } \\
\text { three Lochnagar } \\
\text { corries } \\
\text { mm w.e. }\end{array}$ & $\begin{array}{c}\text { Average snowfall, } \\
\text { two glaciers in } \\
\text { south-east } \\
\mathrm{mm} \text { w.e. }\end{array}$ \\
\hline 10 & o & 200 & I 500 & I 100 & I 840 \\
\hline IO & 5 & 200 & $14^{15}$ & 890 & I $35^{\circ}$ \\
\hline I0 & 5 & 250 & I 375 & I 000 & I 590 \\
\hline IO & 5 & 300 & 1 345 & I 100 & I 830 \\
\hline 30 & 5 & 200 & I 435 & 870 & 1300 \\
\hline 30 & 5 & 250 & I $39^{\circ}$ & 970 & I 530 \\
\hline 30 & 5 & 300 & I 360 & I 070 & 1760 \\
\hline 50 & 5 & 200 & I 460 & 855 & 1265 \\
\hline $5^{0}$ & 5 & $25^{\circ}$ & 1410 & $95^{\circ}$ & I 480 \\
\hline 50 & 5 & 300 & I 375 & 1040 & 1 695 \\
\hline 90 & 5 & 200 & I 500 & 825 & I 195 \\
\hline 90 & 5 & 250 & I 445 & 915 & I 395 \\
\hline 90 & 5 & 300 & 1405 & 995 & I 585 \\
\hline 90 & 5 & $35^{\circ}$ & I 375 & I 075 & 1780 \\
\hline 30 & IO & 250 & I 345 & 835 & I 220 \\
\hline 30 & IO & 300 & 1320 & $9^{20}$ & I 410 \\
\hline 30 & IO & 350 & I 295 & $99^{\circ}$ & I $5^{85}$ \\
\hline 30 & Io & 400 & I 280 & I 070 & 1 765 \\
\hline 90 & Io & 250 & I 400 & 800 & I 145 \\
\hline 90 & 10 & 300 & I 365 & 875 & I 305 \\
\hline $9^{\circ}$ & I0 & 350 & I $34^{\circ}$ & 945 & I 470 \\
\hline 90 & I0 & 400 & I 320 & 1015 & I 630 \\
\hline
\end{tabular}


calculations ranged from o to $90 \%$ by steps of $10 \%$; for $x, 0,5$, 10 and $15 \%$ were used; for the regional ablation-gradient values ranging from $150 \mathrm{~mm} / \mathrm{I} 00 \mathrm{~m}$ by steps of $50 \mathrm{~mm}$ to $500 \mathrm{~mm} /$ roo $\mathrm{m}$ were used. A selection of the results of these calculations, sufficient to indicate the consequences of assigning various values to $w, x$ and $y$, is given in Table III.

In the equation the regional ablation gradient is the major determinant of the former snowfall gradient. As can be seen in Table III, if $w$ and $x$ are held constant at any values, an increase of $50 \mathrm{~mm} / 100 \mathrm{~m}$ in the ablation gradient produces a small increase in average snowfall in the Lochnagar corries but a much larger increase in average snowfall on the two half glaciers in the south-east. The present annual precipitation in the immediate vicinity of the two former glaciers in the south-east is $c$. I $350 \mathrm{~mm}$. If it is accepted as unlikely that precipitation during the stadial significantly exceeded present precipitation (p. $34^{2}$ ), most of the values in the last column of Table III are improbable, especially when it is noted that these values do not include summer precipitation (being related to Norwegian winter-balance data). Low regional ablation gradients ( $150 \mathrm{~mm} / 100 \mathrm{~m}$ with $5 \% A_{\mathrm{b}}, 200 \mathrm{~mm} / \mathrm{I} 00 \mathrm{~m}$ and $150 \mathrm{~mm} / \mathrm{I} 00 \mathrm{~m}$ with $10 \% A_{\mathrm{b}}$ ) are not included in Table III since they lie beyond the range of Liestøl's curve. Snowfall values derived from these combinations of ablation gradient and $A_{\mathrm{b}}$ (calculated from extrapolation of Liestøl's curve) are unrealistic, since they would imply that more continental conditions prevailed in the south-east Grampians during the stadial than prevail today in the more sheltered (from maritime influences) extreme north-east of Jotunheimen. It thus appears that the most satisfactory value for the regional ablation gradient is $200 \mathrm{~mm} / 100 \mathrm{~m}$, unless $10 \% A_{\mathrm{b}}$ is used when 250 or even $300 \mathrm{~mm} / 100 \mathrm{~m}$ appear reasonable (but see below).

Some of the half glaciers were not bordered by steep slopes on which avalanching of snow is likely to have occurred while others were overlooked by proportionately large areas of such slopes. Altering the value of $w$ in the balance equation therefore alters calculated snowfall by different amounts. For example, Mayar and White glaciers, located close together (Fig. I), were very similar in size, shape and aspect, and have almost identical values for $A_{\mathrm{b}}$. However, the potential avalanche area for White half glacier is almost three times that of its neighbour (which almost certainly accounts for the lower altitude of White). The mean altitude difference is $c$. $50 \mathrm{~m}$, suggesting that calculated snowfall for White should be somewhat less than that for Mayar. With an ablation gradient of $200 \mathrm{~mm} / \mathrm{r} 00 \mathrm{~m}$ and $5 \% A_{\mathrm{b}}$ the values given in Table IV are obtained from the balance equation. They suggest $20-30 \% A_{\mathrm{a}}$ as the most satisfactory values.

Table IV. Derivation of the most satisfactory value of $A_{\mathrm{a}}$ for MAYAR AND White glaciers

\begin{tabular}{|c|c|c|c|c|}
\hline $\begin{array}{l}A_{\mathrm{a}} \\
\% \\
\%\end{array}$ & $\begin{array}{c}\text { Altitude of } \\
\text { zero ablation } \\
\mathrm{m}\end{array}$ & $\begin{array}{l}\text { Snowfall } \\
\text { Mayar } \\
\text { mm w.e. }\end{array}$ & $\begin{array}{c}\text { Snowfall } \\
\text { White } \\
\mathrm{mm} \text { w.e. }\end{array}$ & $\begin{array}{c}\text { Snowfall difference } \\
\text { (Mayar minus White) } \\
\text { mm w.e. }\end{array}$ \\
\hline 0 & 1405 & I $33^{1}$ & I 437 & -106 \\
\hline 10 & 1415 & I 299 & $133^{1}$ & -32 \\
\hline 20 & 1425 & 1270 & I 24 I & 29 \\
\hline 30 & I 435 & I 242 & 1165 & 77 \\
\hline $4^{0}$ & I 445 & 1 216 & I 099 & 117 \\
\hline $5^{0}$ & I 455 & 1192 & I 041 & ${ }^{1} 5^{I}$ \\
\hline 90 & 1500 & I 116 & 874 & $24^{2}$ \\
\hline
\end{tabular}

Muick, Glen Clova and Doll glaciers were situated close together, had a similar aspect, and the half glaciers differed in mean altitude by $40 \mathrm{~m}$. Of the three, Muick was the highest and was nourished in slightly higher ground, suggesting the possibility of slightly higher precipitation. However, it may be argued that this tendency may well have been negated by its less favoured location with respect to precipitation associated with south-east winds, and 
that all these glaciers may have been expected to have had a similar snowfall, especially as they are among the larger glaciers and thus less subject to local anomalies. On this basis, using an ablation gradient of $200 \mathrm{~mm} / \mathrm{roo} \mathrm{m}$ and $5 \% A_{\mathrm{b}}$, Table $\mathrm{V}$ suggests that about $35 \%$ is the most appropriate value to assign to $w$ in the balance equation.

Table $V$. Derivation of the most satisfactory value of $A_{\mathrm{a}}$ for Muick, Glen Clova and Doll glaciers

\begin{tabular}{|c|c|c|c|c|c|}
\hline $\begin{array}{l}A_{\mathrm{a}} \\
\%\end{array}$ & $\begin{array}{c}\text { Altitude of } \\
\text { zero ablation } \\
\mathrm{m}\end{array}$ & $\begin{array}{l}\text { Snowfall } \\
\text { Muick } \\
\text { mm w.e. }\end{array}$ & $\begin{array}{l}\text { Snowfall } \\
\text { Glen Clova } \\
\text { mm w.e. }\end{array}$ & $\begin{array}{c}\text { Snowfall } \\
\text { Doll } \\
\text { mm w.e. }\end{array}$ & $\begin{array}{l}\text { Maximum } \\
\text { difference } \\
\text { mm w.e. }\end{array}$ \\
\hline o & 1405 & I 236 & I 174 & $1 \quad 169$ & 67 \\
\hline 10 & $144^{15}$ & 1230 & 1 I 89 & 1182 & 48 \\
\hline 20 & I 425 & 1225 & 1203 & 1194 & 31 \\
\hline 30 & I 435 & 1220 & 1218 & I 206 & 14 \\
\hline 40 & I 445 & 1216 & 1232 & 1218 & 16 \\
\hline $5^{\circ}$ & I 455 & 1212 & I 246 & 1230 & 34 \\
\hline 90 & I 500 & I 203 & 1310 & I 285 & 107 \\
\hline
\end{tabular}

Similar calculations for the three former corrie glaciers on Lochnagar gave $40 \% A_{\mathrm{a}}$ as the most satisfactory value, while Fionn and Gharbh glaciers gave $20-25 \%$. The four sets of results therefore suggest $30 \%$ as the most suitable overall value for $w$ in the balance equation.

Mainly from measurements of snow depth made at the former summit observatory on Ben Nevis, Manley (1959, p. 196) tentatively estimated that "about a third, and possibly rather more, of the snow falling on a windswept summit of this type is likely to be transferred under the lee of the adjacent crags". A much lower transfer of snow is to be expected to have occurred in the south-east Grampians, for they are less exposed and the measured areas of potential snow-blowing are largely valley slopes. Furthermore, the method of measuring areas of potential snow-blowing produces extensive overlap between adjacent quadrants (Fig. 2). Another consequence of the method of measurement is that with any given wind direction only a part of the potential snow-blowing area in a given quadrant could have supplied snow to a glacier. For example, in Figure 2 the part of the south-west quadrant situated south of line $\mathrm{AB}$ and thence along the whole southern side of the glacier could not have supplied snow with a wind from due west. A further point is that part of the snowfall would have been used in smoothing minor ground inequalities before extensive drifting on to glaciers could have occurred. These considerations suggest that values of $x$ in the balance equation should be very low.

Since the measured areas of potential snow-blowing are often large (sometimes far exceeding the area of the associated half glaciers), even small values of $x$ make this factor significant. This is expectable, for the south-east Grampians are characterized by extensive relatively smooth slopes that lead down to the sites of the former glaciers or terminate abruptly in slopes that descended steeply to them. Omission of the wind-blown snow factor from the equation produces unacceptably high snowfall values for the two low-level glaciers in the south-east (e.g. I $750 \mathrm{~mm}$ with $30 \% A_{\mathrm{a}}$ and an ablation gradient of $200 \mathrm{~mm} / 100 \mathrm{~m}$ (see also Table III)) and gives rise to local anomalies in calculated snowfall for other glaciers. Making $x 15 \%$ reduces calculated snowfall on glaciers with a proportionately large $A_{\mathrm{b}}$ to improbably low values and even with $10 \%$ rather low snowfall values result compared with values for adjacent glaciers (e.g. North Carlochy and Corriedoune; Table VI). The greatest consistency between calculated snowfall for adjacent glaciers, taking relative altitude into account, is obtained with $5 \% A_{\mathrm{b}}$.

In summary, it appears that the most suitable values for the balance equation are $30 \% A_{\mathrm{a}}$, $5 \% A_{\mathrm{b}}$ and a regional ablation gradient of $200 \mathrm{~mm} / \mathrm{roo} \mathrm{m}$, this gradient (controlled by Liestøl's graph) resulting in an altitude of zero ablation of $1435 \mathrm{~m}$. Snowfall calculated on this basis for the 27 former glaciers is given in Table VI, column 1 . 
Table Vi. Average annual. snowfall (mm w.e.) and average annual precipitation (mm)

Columns $\mathrm{I}-6$ give calculated snowfall using the following values for the constants in the balance equation: column I, $30 \% A_{\mathrm{a}}, 5 \% A_{\mathrm{b}}$, ablation gradient $200 \mathrm{~mm} / \mathrm{r} 00 \mathrm{~m}$, zero ablation at $\mathrm{I} 435 \mathrm{~m}$; column 2, $30 \% A_{\mathrm{a}}, 5 \% A_{\mathrm{b}}$, ablation gradient $250 \mathrm{~mm} / 100 \mathrm{~m}$, zero ablation at I $390 \mathrm{~m}$; column $3,30 \% A_{\mathrm{a}}, 5 \% A_{\mathrm{b}}$, ablation gradient $300 \mathrm{~mm} / 100 \mathrm{~m}$, zero ablation at $\mathrm{I} 360 \mathrm{~m}$; column $4,20 \% A_{\mathrm{a}}, 5 \% A_{\mathrm{b}}$, ablation gradient $200 \mathrm{~mm} / 100 \mathrm{~m}$, zero ablation at $\mathrm{I} 425 \mathrm{~m}$; column $5,40 \% A_{\mathrm{a}}, 5 \% A_{\mathrm{b}}$, ablation gradient $250 \mathrm{~mm} / 100 \mathrm{~m}$, zero ablation at $\mathrm{I} 400 \mathrm{~m}$; column $6,30 \% A_{\mathrm{a}}, 10 \% A_{\mathrm{b}}$, ablation gradient $250 \mathrm{~mm} / 100 \mathrm{~m}$, zero ablation at I $345 \mathrm{~m}$.

Columns 7-12 give the rankings corresponding to columns $1-6$ (based on the original figures before rounding to the nearest $10 \mathrm{~mm})$. Column 13 gives average annual precipitation derived from column 1 .

\begin{tabular}{|c|c|c|c|c|c|c|c|c|c|c|c|c|c|}
\hline Glacier & I & 2 & 3 & 4 & 5 & 6 & 7 & 8 & 9 & 10 & II & 12 & 13 \\
\hline Lochnagar & 900 & I OIO & I 110 & 920 & 990 & 880 & 23 & 23 & 24 & 23 & 24 & 23 & I 060 \\
\hline Saobhaidhe & 820 & 910 & I OIO & 830 & 910 & 780 & 26 & 26 & 26 & 26 & 26 & 26 & 960 \\
\hline nan Eun & 880 & 980 & 1080 & 880 & 990 & 830 & 24 & 25 & 25 & 25 & 23 & 24 & 1030 \\
\hline Gharbh & 960 & 1090 & 1220 & 970 & 1070 & 900 & 22 & 22 & 22 & 21 & 22 & 22 & 1140 \\
\hline Fionn & 980 & 1110 & I 240 & 970 & I I IO & 910 & 21 & 21 & 21 & 22 & 21 & 21 & I 160 \\
\hline Isla & I 040 & I 200 & I 370 & I IIO & 1130 & I 060 & 20 & 20 & 19 & 19 & 20 & 18 & I 260 \\
\hline Callater & I 260 & I 420 & I 590 & I 270 & 1410 & I 250 & 9 & II & 12 & 10 & II & 9 & I 500 \\
\hline Muick & I 220 & I 380 & I 530 & 1230 & I 370 & 1220 & 12 & 14 & I6 & 14 & 14 & II & I 440 \\
\hline Glen Clova & I 220 & I 380 & I $54^{\circ}$ & I 200 & I 390 & I 220 & 13 & 13 & 14 & 16 & 12 & 12 & I 440 \\
\hline Doll & 1210 & I 370 & I 540 & I 190 & I 390 & I 190 & 14 & 15 & 15 & 17 & 13 & 15 & I 430 \\
\hline Fee & I 250 & I 430 & I 610 & I 240 & I 430 & I 240 & 10 & 10 & I0 & 12 & 9 & 10 & I 500 \\
\hline Mayar & 1240 & I 450 & I 650 & I 270 & 1420 & 1250 & 11 & 9 & 9 & 9 & 10 & 8 & 1510 \\
\hline White & 1160 & I 360 & I 56 & I 240 & I 280 & I 210 & 16 & 16 & 13 & 13 & I 6 & I4 & I 430 \\
\hline Kilbo & $86 o$ & 980 & 1110 & 9io & 930 & 800 & 25 & 24 & 23 & 24 & 25 & 25 & 1040 \\
\hline Winter & 670 & 780 & 890 & 710 & 730 & $54^{\circ}$ & 27 & 27 & 27 & 27 & 27 & 27 & 820 \\
\hline Corrie of Clova & I 470 & 1710 & $195^{\circ}$ & I 520 & I 660 & I 570 & 2 & 2 & 2 & I & 2 & I & I 800 \\
\hline Brandy & I 330 & I $55^{\circ}$ & I 760 & 1380 & I 490 & I 400 & 7 & 7 & 7 & 4 & 7 & 5 & I 620 \\
\hline Wharral & I 190 & I 390 & I 590 & 1260 & I 320 & 1210 & 15 & 12 & 11 & 11 & 15 & I3 & I $45^{\circ}$ \\
\hline Lochanluie & I 120 & I 310 & I 500 & I 210 & 1220 & I 150 & 17 & 17 & 17 & 15 & 17 & 17 & I 360 \\
\hline Keen & I 050 & 1210 & I 370 & I 060 & I 200 & $95^{\circ}$ & 19 & 19 & 20 & 20 & 18 & 20 & I 290 \\
\hline North Carlochy & 1060 & I 240 & I 420 & I 120 & I 170 & 960 & 18 & 18 & I 8 & 18 & 19 & 19 & 1340 \\
\hline Ice cap & 1370 & I 570 & I 780 & I $35^{\circ}$ & I 590 & I 420 & 4 & 5 & 6 & 7 & 4 & 4 & 1650 \\
\hline West & 1390 & 1610 & I 820 & I 370 & I 620 & I 420 & 3 & 3 & 3 & 5 & 3 & 3 & I 690 \\
\hline Effock & I 480 & I 730 & 1980 & I 460 & I $75^{\circ}$ & I 490 & I & I & I & 2 & I & 2 & 1830 \\
\hline South Carlochy & I 340 & I 570 & I 800 & I 400 & I 510 & I 380 & 5 & 6 & 5 & 3 & 6 & 6 & 1700 \\
\hline Corriedoune & 1270 & I 480 & I 690 & I 280 & I 470 & I 170 & 8 & 8 & 8 & 8 & 8 & I 6 & I 590 \\
\hline Berran & 1330 & I 580 & I 820 & I 370 & I 540 & I 270 & 6 & 4 & 4 & 6 & 5 & 7 & I 690 \\
\hline
\end{tabular}

\section{Discussion}

It may appear that the preceding argument is partly invalid in that it is based on accumulation data from Norwegian glaciers that may include wind-blown and avalanched snow. However, Liestøl (personal communication), states that contributions from these sources are "of insignificant value" on the glaciers he used in constructing his curve relating accumulation to summer temperatures. Furthermore, all the preceding calculations (as well as others considered later) were originally made using Ahlmann's (1924) curve relating precipitation to summer temperature (June-September) at the glaciation limit. The inferences made above (e.g. that $30 \% A_{\mathrm{a}}, 5 \% A_{\mathrm{b}}$ and $200 \mathrm{~mm} / \mathrm{r} 00 \mathrm{~m}$ are the most satisfactory values) and the climatic inferences made later remain the same if Ahlmann's curve is used. Since Ahlmann's precipitation values were derived from river gauging stations, it may therefore be concluded that the inferences are not invalidated by being based on Liestøl's curve.

It has been assumed in applying Liestøl's curve that differences in the regional firn-line altitude in the south-east Grampians were wholly a result of differences in snowfall, possible horizontal differences in summer temperature being neglected. Present July mean temperatures (reduced to sea-level) for Braemar and Balmoral, immediately to the north of the area, are 15.1 and $14.8^{\circ} \mathrm{C}$, while for Kettins, south of the Highland edge, the July mean is $15.0^{\circ} \mathrm{C}$. The respective averages for May-September inclusive are $13.0,12.8$ and $13 . \mathrm{I}^{\circ} \mathrm{C}$. No horizontal temperature gradient can be inferred from these figures. Ahlmann (1924) attributed 
$37 \%$ of the eastward rise in the altitude of the glaciation limit from western Norway to eastern Jotunheimen to temperature differences and $63 \%$ to precipitation differences. However, Ahlmann was concerned with a transect of $180 \mathrm{~km}$ compared with the $20 \mathrm{~km}$ of the southeast Grampians, with ground whose relief amplitude is twice as great, and with climates ranging from the highly maritime west of Norway to the rather continental interior. By analogy, one would expect temperature to have contributed no more than a few per cent to the differences in firn-line altitude in the south-east Grampians, its effect being to reduce slightly the differences in snowfall inferred to have existed between the Lochnagar corries and the two low-level glaciers in the south-east. This tendency may well have been compensated by using the regression surface of firn-line altitudes for comparative purposes, for the Lochnagar corries lie above this surface.

A further point is that the glaciers of the south-east Grampians may have begun to form at different times. This possibility cannot be discounted. In the balance equation it would alter the value of $75^{\circ}$ years used in the last term. This value may also be questioned because it is generally accepted in Britain that the stadial lasted about 500 years, from $c$. Io 800 to c. Io 300 radiocarbon years ago. It has been pointed out elsewhere (Sissons, 1974[b]) that the evidence of Manley (1949) combined with that of Coope and others (197I) indicates that glaciers in Scotland began to build up before, perhaps well before, ro 800 B.P. This view is more in accord with Scandinavian evidence, from which Aarseth and Mangerud (1974) have concluded that the Younger Dryas stadial lasted 80o-90o years. Within the range of probable values, the time used in the balance equation has little effect on calculated snowfall. For example, if either 600 or 900 years are used, the greatest effect on the values in column I of Table VI is to alter snowfall derived from Callater glacier by $50 \mathrm{~mm}$ and the least influence is on Berran glacier, where the alteration is $10 \mathrm{~mm}$.

To demonstrate the effect of limited variations in the values for the constants in the balance equation, Table VI has been compiled. Although, for reasons given already, the last five columns of snowfall values are considered improbable, it will be noted that the distribution of snowfall during the stadial, as indicated by the relative values in each column, remains almost exactly the same in all columns. This is shown more clearly by the corresponding rankings given in the next six columns of the table. Kendall's coefficient of concordance (Siegel, r 956) was used to test the degree of association among the rankings. In this test a value of $\mathrm{I}$ indicates perfect agreement. A value of 0.973 was obtained which, when tested against the null hypothesis that the rankings are unrelated to each other, allows this hypothesis to be rejected at the $99.99 \%$ significance level.

\section{Precipitation during the stadial}

In subsequent discussion only the snowfall values given in column I of Table VI will be considered, since these are the most adverse to the argument developed.

In order to obtain average annual precipitation values for the stadial, summer rainfall must be taken into account. In his discussion of the former glaciers in north-west England, Manley (1959) estimated summer rainfall as $20-25 \%$ of total precipitation. In using Ahlmann's ( 1924 ) curve in conjunction with the balance equation, higher values were obtained for precipitation in the south-east Grampians than were obtained for snowfall with Liestøl's curve. This may be partly due to inaccuracies in Ahlmann's curve (of necessity based on indirect evidence) and partly because it relates to the glaciation limit, a theoretical surface generally considered to be situated above the regional firn line (although this difference was probably of little significance in plateau country such as the south-east Grampians). If these possibilities are neglected, comparison of the values derived for the south-east Grampians from Ahlmann's and Liestøl's curves suggests that $22 \%$ of total precipitation was summer rain. 
Liestøl (personal communication) states that a rough calculation indicates that $31 \%$ of the annual precipitation at the equilibrium line on Storbreen is rain.

In converting the snowfall values to annual precipitation values, lower percentages were used (being adverse to the argument below) and the variation in altitude of the glaciers was taken into account, for glaciers at lower altitudes probably received a greater proportion of their total precipitation as rain. It was assumed that $15 \%$ of total annual precipitation at $900 \mathrm{~m}$ was rain and $20 \%$ at $600 \mathrm{~m}$, the snowfall values in column I of Table VI being converted to precipitation values using the mean altitudes of the half glaciers. The results are given in the last column of Table VI.

In almost all the calculations using the balance equation improbably low snowfall values were obtained for Kilbo and Winter glaciers (e.g. Table VI). These results are rejected. They are produced by the exceptionally large areas measured for potential snow-blowing and avalanching for these glaciers. They show that inferences about former precipitation (or snowfall) should not be based on the result from a single glacier, it being essential to assess each result in relation to those for adjacent glaciers.

Figure $4 \mathrm{~A}$ gives the distribution of annual precipitation as inferred from 25 former glaciers (Winter and Kilbo excluded), isohyets having been drawn taking relief into account. It shows that precipitation was low in the north and especially in the north-west, there being a pronounced decline in amount across the areas of highest ground, particularly evident when it is noted that the glaciers to the north of the high ground are at much higher altitudes than those immediately to the south. Thus Keen glacier may be contrasted with North Carlochy; the three Lochnagar corrie glaciers with Muick; and Fionn and Gharbh with Isla. High precipitation occurred in the south-eastern part of the area, with values $70-80 \%$ greater than at the Lochnagar corries despite much lower altitude.

A local feature of the precipitation distribution is the westward increase indicated by the four south-facing glaciers on the north side of Glen Clova, with calculated values of I 360 , I 450, I 620 and I $800 \mathrm{~mm}$ for Lochanluie, Wharral, Brandy and Corrie of Clova, respectively. This may well be the result of snow-bearing air streams from the south-east having been channelled along Glen Clova, resulting in marked uplift and consequent heavy precipitation as the air rose out of the glen as it became increasingly constricted northward. The strongest uplift would have occurred at Corrie of Clova (the largest corrie in the group, with the largest former glacier and the highest calculated precipitation) for opposite here the glen narrows abruptly.

The heavy precipitation indicated, particularly by Brandy and Corrie of Clova glaciers, suggests heavy precipitation also over the adjacent part of the ice cap, located at a higher altitude, and over the intervening high ground. The figure of $\mathrm{I} 650 \mathrm{~mm}$ obtained for the ice cap is clearly a generalization for a large area; heavy precipitation on its southern part would imply relatively low precipitation on its northern part.

The present distribution of precipitation, based on the i : 625000 rainfall map, is given in Figure ${ }_{4} \mathrm{~B}$. Comparison of this map with Figure $4 \mathrm{~A}$ shows (so far as the limitations of modern and ancient data permit) that in the extreme south-east former precipitation considerably exceeded that of today, the difference probably being $c .300 \mathrm{~mm}$. North-westward, on to the high ground north of Glen Clova, this excess gradually diminished. Still farther west and north-west, in glens Doll, Clova and Muick and the head of Glen Callater, the former glaciers indicate rather lower precipitation than prevails today. In the extreme west, Fionn and Gharbh glaciers point to amounts about $400 \mathrm{~mm}$ lower during the stadial. At the present day, precipitation apparently declines markedly northward from the summit of Lochnagar (Fig. 4B). A similar decline (but with lower absolute values) is indicated by the Lochnagar corrie glaciers. In the north-east, the precipitation value for Keen glacier implies former slightly lower precipitation, while the absence of evidence for other former glaciers in this area of relatively high ground is consistent with this interpretation. 

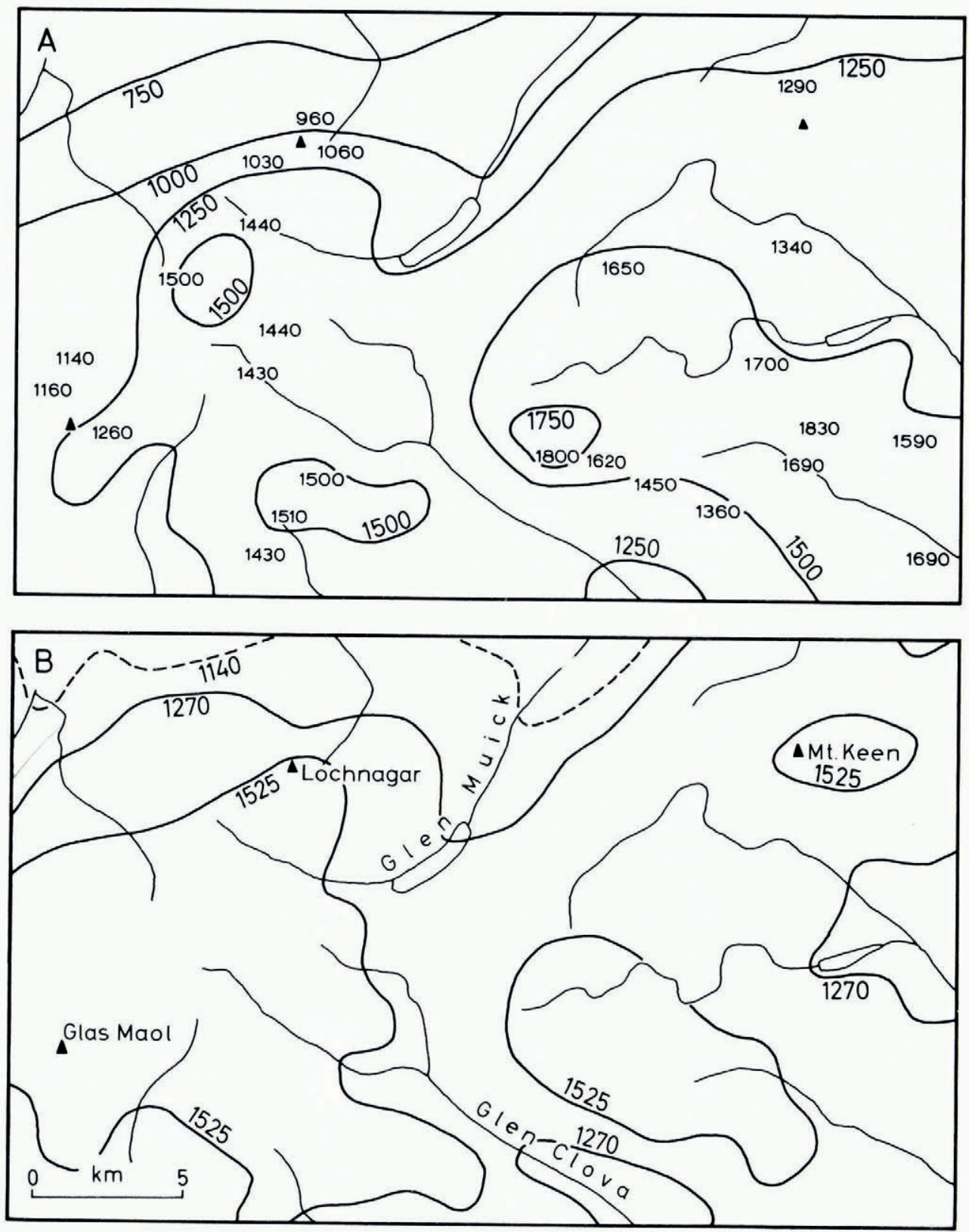

Fig. 4. A. Average annual precipitation during the Loch Lomond stadial in the south-east Grampians. Calculated precipitation $(\mathrm{mm})$ for 25 glaciers is indicated. Isohyets are at $250 \mathrm{~mm}$ intervals. B. Present precipitation, after 1: 625 ooo Ordnance Survey map, on which isohyets in the area are at 45, 50 and 60 in. 
In summary, despite the use of the lowest reasonably justifiable values, it appears that precipitation in the south-east Grampians as a whole during the stadial differed little from that of today. On the other hand, its distribution was different, with higher values in the south-east and lower values in the north and north-west. Such a pattern indicates that precipitation associated with south-easterly air streams was relatively more important than it is today. This is expectable in view of the probably diminished contribution from both easterly and westerly air streams (p. 332), which implies that precipitation associated with south-easterly air streams was absolutely more important than at the present time. When the much lower moisture-holding capacity of saturated air, caused by much lower temperatures, is taken into account, the conclusion that precipitation associated with south-easterly air streams was very much more frequent than today appears inescapable.

One factor that may have contributed to this difference is suggested by Goldie's (I93I) discussion of present precipitation in eastern Scotland. Having pointed out that it is exceptional for heavy precipitation at Aberdeen to be associated with tropical maritime air streams from the south-east, he continued (Goldie, I93I, p. 7): "In mountainous districts on the other hand, under suitable conditions, very heavy and continuous rainfall may occur in equatorial [i.e. tropical maritime] air. The ideal conditions occur in winter when the land is cold, and especially if cold air or locally chilled air, virtually detached from the upper circulation, is lying about in the valleys and assists in forming a good smooth sliding surface over the whole mountainous region. Then the mountains, 'stream-lined' by the cold air, act like a steering surface to produce what is virtually 'warm-front' rainfall." The quotation appears to be particularly applicable to the south-east Grampians during the stadial, when extensive ice and snow surfaces, as well as the accumulation during relatively calm spells of dense cold air in valleys (promoted by glacier winds), would facilitate the development of Goldie's "smooth sliding surface".

Another contributory factor is suggested by Hay's (1949, p. I I) discussion of present autumn and winter precipitation in eastern Scotland. He wrote: "The eastward movement of a trough of low pressure is sometimes hindered by an anticyclone centred over Scandinavia, and, in these circumstances, heavy falls of rain tend to occur in east Scotland. The pressure gradient, in these and other cases when large falls occurred, is often favourable for strong steady S.E. winds which begin to blow up to 12 hours before the commencement of the rain and last through most of the period of the fall." With the presence of an ice sheet over most of Scandinavia tending to induce an anticyclone there during the stadial, it seems likely that the conditions required by Hay would have occurred more frequently than at present. This situation, however, may well have been only a part of a larger pattern that is discussed later.

\section{SUMmer TEMPERATURES DURING THE STADIAL}

Former summer temperatures may be derived from Liestøl's graph relating accumulation to summer (May-September) temperature at the equilibrium line in Norway. It is convenient to consider initially the regional firn line computed for the glaciers when in equilibrium at their greatest extent. Since climate had ameliorated very little at this time compared with the average conditions during the growth of the glaciers (see below), snowfall values already calculated (Table VI, column I) may be used for this purpose. Average snowfall for the two low-level glaciers in the extreme south-east, for which the computed equilibrium firn-line altitude averages $530 \mathrm{~m}$, was calculated as $1300 \mathrm{~mm}$, which corresponds to a summer temperature of $1.3^{\circ} \mathrm{C}$ on Liestøl's graph. With a temperature increase of $0.6 \mathrm{deg} / \mathrm{room}$ descent, this indicates a May-September average temperature at sea-level of $4.5^{\circ} \mathrm{C}$. Using the average present-day difference between mean May-September and mean July temperatures for three meteorological stations near the south-east Grampians, this is equivalent to a July sea-level temperature of $6.5^{\circ} \mathrm{C}$. 
An indication of average temperature conditions during the growth of the glaciers is obtained by calculating average net annual ablation on the half glaciers

$$
{ }_{10}{ }^{3} S\left(A_{\mathrm{g}}+0.3 A_{\mathrm{a}}+0.0{ }_{5} A_{\mathrm{b}}\right)-\frac{\mathrm{10}^{8} V \times 0.9}{75}
$$

and converting this to average annual percentage loss in volume. This shows that on almost all the glaciers the volume of snow and ice ablated (on average) each budget year was equivalent to well over $90 \%$ of the snow that had accumulated during that budget year. The highest percentage (97) was for Berran glacier and the lowest percentage (84) was for Callater and Muick glaciers. These figures suggest that average summer temperatures during the stadial were little below the summer temperatures calculated for the time the glaciers were in equilibrium; in fact, on average, most of the glaciers just managed to develop. Manley (e.g. I95 I, I 953) has frequently emphasized the range of variation of the present and very recent British climate and has inferred that similar variations typified the climate in the past. He has shown that decadal running means of temperature (more relevant than the values for individual years when considering former glaciers), both seasonal and annual, have ranged over 2 deg during the last 300 years. Superimposing such oscillations on the marginally favourable average climate for glacier development during the stadial gives a more realistic situation and strongly suggests that the overall advance was interrupted from time to time by periods of retreat.

Using evidence of a type not available in the south-east Grampians, it was possible to infer that, during at least part of the time the Gaick plateau ice cap accumulated, average summer temperature was approximately $0.5 \mathrm{deg}$ lower than when the ice cap was in equilibrium (Sissons, 1974[a]). Since this former ice cap was located only 25-6o km west of the western margin of the present area, a similar difference may be inferred for the latter. Thus sea-level July temperature for at least part of the stadial was probably $c .6 .0^{\circ} \mathrm{C}$, which is $c .9 .0 \mathrm{deg}$ below present. Manley (1959, 1964) inferred stadial July mean temperatures (close to sea-level) of $7 \cdot 5^{-} 8^{\circ} \mathrm{C}$ for the Lake District, 8- $9^{\circ} \mathrm{C}$ for North Wales and $10^{\circ} \mathrm{C}$ for the north English Midlands, while Coope and others (197 I) proposed a temperature for the Midlands of $10^{\circ} \mathrm{C}$ or just below.

Although the summer temperature for the south-east Grampians is in general accord with these results, it does appear to be rather low. This is particularly evident in the comparison with the Lake District located on the western side of Britain with its relatively cool summers. The July temperature of $6.0^{\circ} \mathrm{C}$ derived for the south-east Grampians is also low in relation to the $7.1^{\circ} \mathrm{C}$ inferred for the Gaick ice cap. The latter figure was based on an assumed precipitation of $80 \%$ of the present value, but this assumption now appears reasonable in the light of preceding discussion. (If a higher precipitation is assumed for the Gaick ice cap, the discrepancy is increased.) Both the Lake District and Gaick inferred temperatures were based on Ahlmann's curve, yet if Liestøl's curve is used former temperature differences between these areas and the south-east Grampians are increased. The most likely reason for these differences is that the south-east Grampians had much more cloudy summers than at present. This in turn could well have been the result of much more frequent winds from an easterly point, especially south-east. At the present time, such winds, particularly in spring and early summer, are associated with sea (and coastal) fog; if the winds are strong enough, low stratus cloud covers the south-east Grampians, clearing only, if at all, during the heat of the day. Lower sea and air temperatures during the stadial would have favoured such conditions, while snow and ice on the uplands would have encouraged the formation and retention of the cloud cover.

Of the areas affected by the Loch Lomond re-advance in Scotland, the south-east Grampians are unique in the way they would have been influenced by south-east winds. They are also unique in possessing a group of large south-facing corries (Wharral, Brandy and Corrie of Clova). It is therefore difficult to resist the conclusion that the glaciers that occupied these corries during the stadial (along with adjacent south-facing Lochanluie glacier) were 
able to survive owing to very cloudy summers. The corries themselves, however, were not formed during the stadial, for the volume of the glacial deposits is paltry compared with that of the corries. It may therefore be concluded that climatic conditions similar to those of the Loch Lomond stadial occurred repeatedly during the Quaternary. The same conclusion is indicated by the similarity between the regional trend in corrie altitudes in the south-east Grampians (e.g. Robinson and others, 1971) and the altitudes of the regional firn line. Such climatic conditions could not have applied when large ice sheets existed, for the adjacent North Sea bed and the south-east Grampians themselves were buried beneath the ice. Hence, while the Loch Lomond re-advance and the climate that produced it represent a unique event in the Quaternary history of at least the last 20000 years, similar situations must have existed on many occasions during the Quaternary.

WiNTER TEMPERATURES AND ANNUAL RANGE OF TEMPERATURE DURING THE STADIAL

Winter temperatures cannot be inferred from the former glaciers. However, even in western Scotland permafrost existed down to sea-level during the stadial (Sissons, 1974[b]). Since a mean annual temperature no higher than $-1^{\circ} \mathrm{C}$ is required for the development of permafrost, a January temperature at sea-level at least as low as $-8^{\circ} \mathrm{C}$ is indicated for the south-east Grampians. This means that the annual range was at least $c$. 14 deg, compared with the present $c .12^{\circ} \mathrm{C}$. A more continental climate than now would have been favoured by the bed of the southern North Sea then being land and by the probability that the northern part was partly or wholly frozen over in winter. The Scandinavian ice sheet would also have been a favourable factor.

An additional factor relates to long-term variations in solar radiation. Vernekar (I97I) has produced tables showing the amount of solar radiation received at the top of the atmosphere taking into account time, latitude, eccentricity of the Earth's orbit, obliquity of the ecliptic and longitude of perihelion. Following Milankovitch (1930), he divided the year into two parts of equal duration such that the heat received during any day of the summer half ("caloric summer") is greater than that of any day of the winter half ("caloric winter"). At lat. $55^{\circ} \mathrm{N}$. present-day (1950) average quantities of radiation received are 256 and 819 langleys/d ( 10.7 and $34.3 \mathrm{MJ} \mathrm{m}^{-2} \mathrm{~d}^{-1}$ ) for the caloric winter and summer, respectively. Table VII shows, for this latitude, percentage deviations from present of the amounts of solar radiation at various dates B.P. It can be seen that the stadial corresponds with a period of maximum difference between winter and summer solar radiation received, the greatest difference in fact during the last 50 ooo years.

Table ViI. Percentage deviations from present of the amounts of solar radiation

\begin{tabular}{lrrrrrrrrrr}
\multicolumn{1}{c}{ Years B.P. } & \multicolumn{1}{c}{6 000 } & 7000 & 8000 & 9000 & 10 000 & I I 000 & 12000 & 13000 & 14000 & 15000 \\
Caloric winter & -6.64 & -8.59 & -9.77 & -10.94 & -11.72 & -12.11 & -11.72 & -10.94 & -9.77 & -7.81 \\
Caloric summer & 2.44 & 3.05 & 3.54 & 3.91 & 4.15 & 4.15 & 4.02 & 3.79 & 3.30 & 2.69
\end{tabular}

\section{WIDER CLIMATIC CONSIDERATIONS}

In view of the various (and collectively important) factors that operated or were likely to have operated to reduce precipitation in the south-east Grampians during the stadial, the factors tending to operate in the opposite sense that have so far been proposed appear inadequate to result in a precipitation similar to that of the present. One must therefore infer that the major factor in the latter category was a much more vigorous atmospheric circulation, with more frequent fronts, stronger winds and greater cloud cover (associated with frontal systems as well as resulting from the special consequences of south-east winds) affecting the 
south-east Grampians. Manley (r959) made similar inferences based on the Lake District glaciers that developed during the stadial. Yet there was sufficient sunshine in the south-east Grampians, at least in summer, to cause glacier altitude and aspect to show a clear relationship to direct solar radiation.

A more vigorous circulation than now, implying stronger maritime influence, initially seems inconsistent with the more continental climate that has been proposed and particularly with the existence of permafrost down to sea-level. The evidence for very cold conditions in Scotland during the stadial also at first appears difficult to reconcile with the inferences of Ruddiman and McIntyre (1973), based on cores from the floor of the Atlantic Ocean, that deglacial warming of the North Atlantic adjacent to the British Isles occurred about i 3500 B.P., cold polar water having retreated far to the west by 13 ooo B.P. Their view accords with Coope and Brophy's (1972) conclusion, based on Coleoptera, that rapid climatic amelioration occurred around $\mathrm{I} 3$ Ooо B.P. In accord also is the estimate, based on radiocarbondated pollen sites, that the last ice sheet had disappeared from Scotland by 12500 B.P. (Sissons and Walker, 1974).

Despite this evidence, it appears that the only way in which the climate of the stadial in Scotland can be explained is by invoking the return of the cold polar water. Ruddiman and McIntyre recognized a temporary reversal of the trend they had described but, having insufficient evidence, drew a very tentative limit to polar water during the stadial, a limit that was placed far out in the Atlantic Ocean. However, Peacock (1974) has described a sequence of deposits from the floor of the Cromarty Firth, on the east coast of northern Scotland, in which the Loch Lomond stadial is represented by $13 \mathrm{~m}$ of sediment with molluscs and microfauna indicative of very cold water. Similar sequences have been found by boring at several points in the sea bed off western Scotland and at one site studied in detail a cold sea during the stadial is recorded by Foraminifera and dynoflagellate cysts from $10 \mathrm{~m}$ of sediment (Binns and others, 1974). While cooling by melt waters from the glaciers that developed during the stadial must have affected sea temperatures around Scotland, the possibility clearly exists that this sea-bed evidence demonstrates the return of polar water. How far south the cold water extended is at present unknown. Yet, speculating further, it may well be that the junction of polar and relatively warm (North Atlantic Drift) waters was in the immediate vicinity of the British Isles during the stadial. In such a situation, the contrasting sea temperatures would have encouraged the vigorous interaction of air masses that would have resulted in stormy conditions and abundant precipitation in much of the British Isles, many of the depressions following more southerly tracks than prevail today. The latter would have been particularly important in providing the inferred precipitation in the south-east Grampians. Here much of the precipitation would have fallen through cold south-easterly air streams in advance of warm and occluded fronts (a considerable proportion of which probably did not actually move across the south-east Grampians) and, over Scotland as a whole, winds from an easterly point would have been more frequent than they are today (although they would not have been the prevailing winds). Such a situation, together with the low temperatures of the adjacent sea, seems able to account for the low temperatures and greater continentality during the stadial while at the same time allowing the frequent precipitation necessary to produce the glaciers of the Loch Lomond stadial.

\section{Acknowledgement}

The writers are very grateful to Dr O. Liestøl for allowing them to use his unpublished temperature/accumulation graph. 


\section{REFERENCES}

Aarseth, I., and Mangerud, J. 1974. Younger Dryas end moraines between Hardangerfjorden and Sognef jorden, western Norway. Boreas, Vol. 3, No. 1, p. 3-22.

Ahlmann, H. W. 1924. Le niveau de glaciation comme fonction de l'accumulation d'humidité sous forme solide. Geografiska Annaler, Årg. 6, Ht. 3, p. 223-72.

Binns, P. E., and others. 1974. Glacial and post-glacial sedimentation in the Sea of the Hebrides, by P. E. Binns, R. Harland and M. J. Hughes. Nature, Vol. 248, No. 545 I, p. $75^{\mathrm{I}-54}$.

Bleasdale, A., and Rowsel, E. H. I967. Map of average annual rainfall 19I6-1950. Chessington, Surrey, Ordnance Survey.

Chorlton, J. C., and Lister, H. 1971. Geographical control of glacier budget gradients in Norway. Norsk Geografisk Tidsskrift, Bd. 25 , Ht. 3-4, p. ${ }_{159-64}$.

Clarke, P. J., and Evans, F. C. 1954. Distance to nearest neighbour as a measure of spatial relationships in populations. Ecology, Vol. 35, No. 4, p. 445-53.

Coope, G. R., and Brophy, J. A. 1972. Late-glacial environmental changes indicated by a coleopteran succession from North Wales. Boreas, Vol. I, No. 2, p. 97-142.

Coope, G. R., and others. I 971 . Fossil Coleoptera as indicators of climatic fluctuations during the last glaciation in Britain, by G. R. Coope, A. Morgan and P. J. Osborne. Palaeogeography, Palaeoclimatology, Palaeoecology, Vol. 1o, No. 2, p. 87-101.

Dixon, W. J. 1973. BMD biomedical computer programs. University of California Publications in Automatic Computation, Vol. 2, p. 305-30.

Ferguson, H. L., and others. 1971. Theoretical clear-sky effective insolation over a small mountain basin, by H. L. Ferguson, H. F. Cork, R. L. Andersen, S. Mastoris and B. Weisman. Canada. Environment Canada. Atmospheric Environment Service. Climatological Studies, No. 21.

Fraser, C. I966. The avalanche enigma. London, John Murray.

Geiger, R. 1971. The climate near the ground. Third printing. Cambridge, Mass., Harvard University Press.

Goldie, A. H. R. 1931. Characteristics of rainfall distribution in homogeneous air currents and at surfaces of discontinuity. G.B. Meteorological Office. Geophysical Memoirs, No. 53.

Goodison, B. 1972. The distribution of global radiation over Peyto Glacier, Alberta. Ottawa, Environment Canada. Inland Waters Directorate. Water Resources Branch. (Scientific Series, No. 22.)

Hay, R. F. M. 1949. Rainfall in East Scotland in relation to the synoptic situation. G.B. Meteorological Office. Professional Notes, No. 98.

Liestøl, O. 1967 . Storbreen glacier in Jotunheimen, Norway. Norsk Polarinstitutt. Skrifter, Nr. 141.

Manley, G. 1949. The snowline in Britain. Geografiska Annaler, Årg. 31, p. I 79-93.

Manley, G. I951. The range of variation of the British climate. Geographical fournal, Vol. 1 1 7, Pt. 1, p. $43-68$.

Manley, G. 1953. The mean temperature of central England, i698-1952. Quarterly Journal of the Royal Meteorological Society, Vol. 79, No. 340, p. 242-61.

Manley, G. 1959. The late-glacial climate of north-west England. Liverpool and Manchester Geological Journal, Vol. 2, Pt. 2, p. 188-2 I5.

Manley, G. 1964. The evolution of the climatic environment. (In Watson, J. W., and Sissons, J. B., ed. The British Isles: a systematic geography. Edinburgh, Thomas Nelson, p. 152-76.)

Milankovitch, M. r930. Mathematische Klimalehre und astronomische Theorie der Klimaschwankungen. (In Köppen, W., and Geiger, R., ed. Handbuch der Klimatologie. Bd. I, Teil A. Berlin, Verlag Borntraeger, p. $1-176$.

Paterson, W. S. B. 1969. The physics of glaciers. Oxford, etc., Pergamon Press. (The Commonwealth and International Library. Geophysics Division.)

Peacock, J. D. r974. Borehole evidence for late- and post-glacial events in the Cromarty Firth, Scotland. Bulletin of the Institute of Geological Sciences of the United Kingdom, Vol. 48, p. 55-67.

Robinson, G., and others. 1971. Trend surface analysis of corrie altitudes in Scotland, [by] G. Robinson, J. A. Peterson and P. M. Anderson. Scottish Geographical Magazine, Vol. 87, No. 2, p. 142-46.

Ruddiman, W. F., and McIntyre, A. 1973. Time-transgressive deglacial retreat of polar waters from the North Atlantic. Quaternary Research, Vol. 3, No. 1, p. 117-30.

Schytt, V. 1967. A study of ablation gradient. Geografiska Annaler, Vol. 49A, Nos. 2-4, p. 327-32.

Siegel, S. 1956. Nonparametric statistics for the behavioral sciences. New York, McGraw-Hill.

Sissons, J. B. 1972. The last glaciers in part of the south-east Grampians. Scottish Geographical Magazine, Vol. 88, No. 3 , p. 168-8I.

Sissons, J. B. 1974[a]. A late-glacial ice cap in the central Grampians, Scotland. Institute of British Geographers. Transactions, No. 62, p. 95-114.

Sissons, J. B. 1974[b]. The Quaternary in Scotland: a review. Scottish Journal of Geology, Vol. 10, No. 4, p. $311-37$.

Sissons, J. B., and Grant, A. J. H. 1972. The last glaciers in the Lochnagar area, Aberdeenshire. Scottish Journal of

Geology, Vol. 8, No. 2, p. 85-93.
Sissons, J. B., and Walker, M. J. C. 1974. Late-glacial site in the central Grampian Highlands. Nature, Vol. 249,

No. 546o, p. 822-24.
Vernekar, A. D. r971. Long-period global variations of incoming solar radiation. Meteorological Monographs, Vol. 12, No. 34. 